\title{
KEKUATAN BAHAN TALI TAMPAR
}

\author{
Edi Hari Purwono ${ }^{1}$ Bambang Yatnawijaya ${ }^{2}$ \\ 1 Jurusan Arsitektur Fakultas Teknik, Universitas Brawijaya \\ 2 Jurusan Arsitektur Fakultas Teknik, Universitas Brawijaya \\ Alamat Email penulis : haripurwono73@gmail.com
}

\begin{abstract}
ABSTRAK
Salah satu sistem konstruksi dan struktur yang harus dipelajari oleh seorang perancang atau arsitek adalah konstruksi dan struktur bentang panjang. Aplikasi struktur bentang panjang yang menggunakan kabel sebagai penyangga utama dirasa terlambat berkembang di Indonesia yang seharusnya di beberapa negara maju sudah banyak pengaplikasian bangunan bentang panjang dengan struktur kabel. Faktor utama yang menjadi sebab kurang berkembangnya struktur kabel di Indonesia adalah belum adanya pengetahuan tentang kekuatan bahan dalam pembuatan model menggunakan tali tampar plastik yang mudah ditemui di pasaran. Tali tampar plastik ini dianggap mampu menginterpretasikan kabel baja dalam skala kecil. Untuk itulah penelitian ini dilakukan agar masyarakat umum maupun kalangan akademika mampu mengetahui seberapa besar kekuatan bahan tali tampar untuk pembuatan model dalam satuan berat dan waktu jika dibandingkan dengan kabel baja. Metode yang digunakan adalah metode empiris eksperimental dengan cara pengujian bahan uji pada alat yang telah disediakan. Selain itu juga menggunakan metode konten analisis yang dilakukan pada sumber literatur dan penelitian sebelumnya yang digunakan untuk mendapatkan data-data yang dibutuhkan, bersumber pada aspek kekuatan bahan tali tampar sebagai struktur kabel. Percobaan yang dilakukan tidak menunjukan akurasi ukuran yang rinci namun dengan batasan nilai tertentu yang dapat dilihat oleh mata dan indera.
\end{abstract}

Kata kunci: Kata kunci : Kekuatan bahan, tali tampar

\begin{abstract}
One of the construction systems and structures to be learned by a designer or architect is the construction and long-span structures. Application of long-span structures using cable as the main buffer in Indonesia is considered late whereas in some developed countries have been well developed. The main factors which may be considered the cause of this case is the lack of material knowledge which is synthetic rope. Synthetic rope is considered as capable as steel cable on a small scale. This research is conducted for public and academics to know how far is the strength of synthetic rope for modeling compared to steel cable. The method used is an experimental method of empirical testing by the test material on the tools that have been provided. Additionally, content analysis method in literature source and previous research is also used to get the data needed. Experiments conducted did not show the detailed measurement accuracy but with a certain value limit that can be seen by the eyes and senses.
\end{abstract}

Keywords: Strength of materials, synthetic rope 


\section{Pendahuluan}

Pekerjaan seorang perancang atau Arsitek seringkali berhubungan dengan pembuatan model detail secara berskala. Pembuatan model berskala ini tentu saja sangat penting untuk mengembangkan rancangan secara baik dan benar sebelum hasil rancangan diaplikasikan secara nyata di lapangan.

Salah satu cara mengembangkan perancangan pada detail - detail arsitektural pada seperangkat konstruksi yang keberadaanya di dalam maupun di luar bangunan yaitu keadaan dimana konstruksi terpapar (exposed) secara jelas adalah dengan pembuatan model berskala agar detail yang bersangkutan terlihat dengan jelas serta dapat dipelajari oleh seortang arsitek.

Penelitian ini dirasa perlu karena salah satu kompetensi utama oleh seorang arsitek adalah mampu merancang dan menjadikan elemen - elemen konstruksi ataupun struktural yang terpapar menjadi elemen - elemen yang estetis.

Salah satu sistem konstruksi dan struktur yang harus dipelajari oleh seorang perancang atau arsitek adalah konstruksi dan struktur bentang panjang. Aplikasi struktur bentang panjang yang menggunakan kabel sebagai penyangga utama dirasa telat berkembang di negara Indonesia yang mana seharusnya di beberapa negara maju sudah banyak pengaplikasian bangunan bentang panjang dengan struktur kabel. Faktor utama yang mungkin dirasa menjadi sebab kurang berkembangnya struktur kabel di Indonesia adalah belum adanya pengetahuan mengetahui kekuatan bahan pembuatan model yang tak lain adalah tali tampar plastik yang ada di pasaran.

Tali tampar plastik ini dianggap mampu menginterpresentasikan kabel baja dalam skala kecil. Untuk itulah penelitian ini dilakukan agar masyarakat umum maupun kalangan akademika mampu mengetahui seberapa besar kekuatan bahan tali tampar untuk pembuatan model dalam satuan berat dan waktu jika dibandingkan dengan tali kabel baja yang nantinya akan dibahas pada bab selanjutnya.

\section{Studi Pustaka}

\subsection{Kekuatan Material}

Pengujian kekuatan material sudah pernah dilakukan di jaman awal Renaissance, tapi ini tidak pernah dijalankan secara sistematik sampai abad 17. Pengujian dilakukan hanya pada spesimen ukuran-penuh, seringkali dengan menggunakan cannon ball (bola meriam), yang merupakan satu-satunya bobot yang berat dan akurat di saat itu (Gambar 1).

Di abad 18, pengujian menggunakan mesin yang memiliki beberapa tuas untuk melipatgandakan efek dari pemberat kecil (Gambar 1). Selain itu, spesimen dibuat sekecil mungkin. (Cowan, 1977)

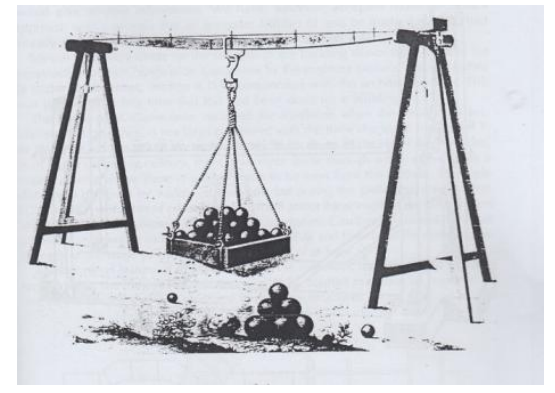

Gambar 1. Pengujian kekuatan tiang kayu ukuran-penuh, dengan menggunakan cannon ball sebagai pemberat.

sumber: Cowan, 1977 
Pengujian ini sudah dilakukan dengan metode sederhana hingga yang komplek. Pada saat ini juga perlu digunakan pengujian bahan material untuk mengukur ketahanan suatu benda agar dapat diaplikasikan pada penggunaan material ini pada suatu sistem tertentu.

\subsection{Elastikitas Material Dan Teori Bending}

Temuan elastikitas dihubungkan dengan nama Robert Hooke, yang dikenal lewat karyanya tentang microscopy. Dia adalah seorang surveyor Kota dan arsitek beberapa gereja yang dibangun setelah Great Fire. Dalam bukunya tentang helioscope, dia mengemukakan anagram:

Teori Elastikitas atau Kepegasan sebenarnya dan sebuah Eksplikasi selalu ditemukan di beberapa subyek. Inilah cara menghitung kecepatan benda yang bergerak.

Ambil sebuah tali dawai yang panjangnya 20, 30 atau 40 kaki, dan ikat bagian ujungnya dengan paku, dan ujung lainnya dipasang sebuah Timbangan (skala) untuk diberi pemberat. Lalu, buat jarak sejengkal antara bagian bawah timbangan dan ground atau lantai di bawahnya. Tetapkan jaraknya, dan berikan pemberat di timbangan, dan ukur beberapa rentangan yang terjadi pada dawai.

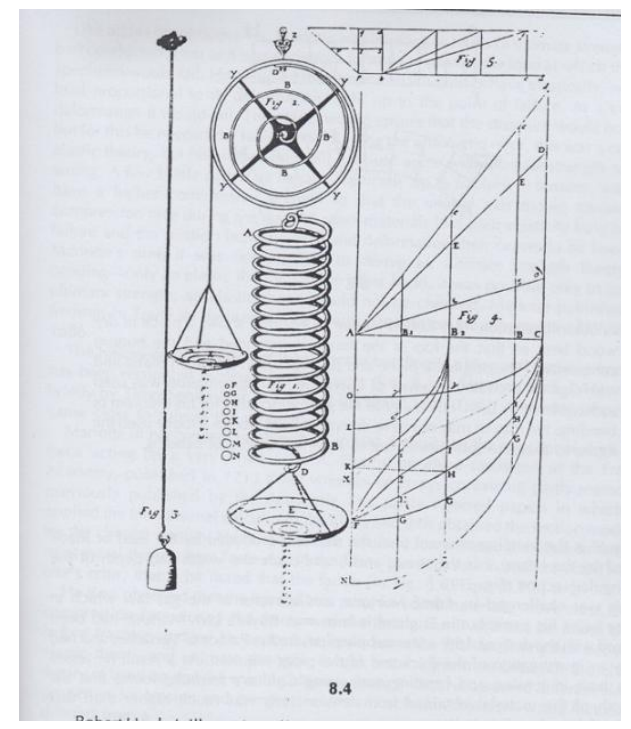

Gambar 2. Ilustrasi Robert Hooke tentang pengujian pegas dan tali elastis sumber: Cowan, 1977

Dalam penelitian menghitung kekuatan benang nilon pada penelitian karakteristik benang pancing nilon menggunakan metode tarik juga menggunakan asas Hook (Kiay,2011) dengan percobaannya sebagai berikut :

Tegangan dan regangan tali pancing nilon digunakan rangkaian alat sederhana berupa tali pancing nilan dengan digantung secara vertikal dengan ujung atas diikat dengan pangkal tali diberi beban yang berbeda-beda. 


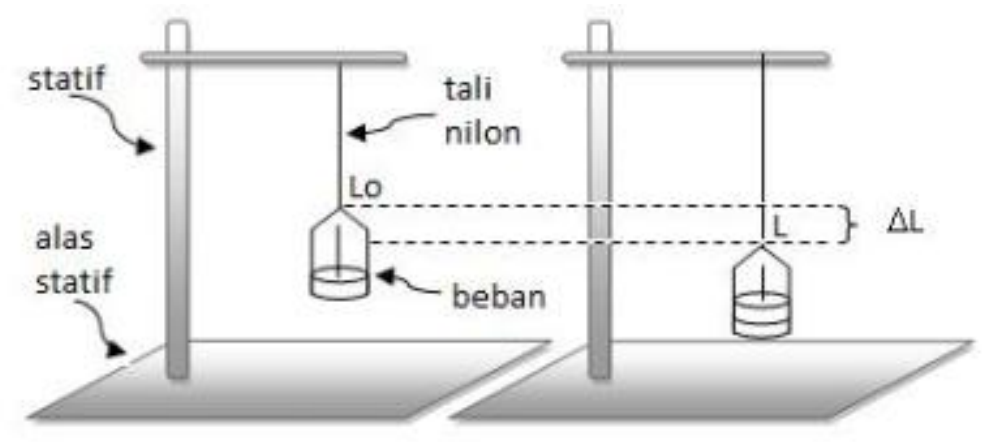

Gambar 3. Desain alat RBL dengan metode uji tarik Sumber: Kaiy,2011

Pada penelitian pengujian tarik (Wikana,2007) dilakukan pengujian tarik untuk mengetahi kuat tali rami, dengan cara memasang tali pada dua tumpuan jepit lalu ditarik hingga tali menjadi tegang tetapi beban masih menunjukan angka nol. Secara bertahap beban dinaikan dan pemanjangan tali dilihat setiap saat setiap kelipatan beban tertentu. Perpanjangan dapat dilihat pada dial gauge sedang besar beban dapat dilihat pada alat ukurdigital.

Penelitian pengujian komposit serat sansevieria (Fajri,2013) menggunakan uji kekuatan mekaniknya dengan menggunakan mesin uji tarik. Pengujian ini dilakukan untuk mengetahui besarnya kekuatan tarik bahan komposit menurut standar ASTM D638-03. Penelitian bahan pada beberapa uji coba kekuatan serat bahan menggunakan uji tarik sehingga diketahui batasan kekuatan keelastisan bahan tersebut sehingga, pada penelitian kekuatan serat pada tali tampar ini juga mengguanakan uji kekuatan tarik.

\subsection{Metode Penelitian}

Metode yang digunakan adalah metode empiris eksperimental dengan cara pengujian bahan uji pada alat yang telah disediakan. Peneliti bertindak sebagai instrumen utama. Selanjutnya metode content analysis dilakukan pada sumber literatur atau penelitian sebelumnya yang digunakan untuk mendapatkan data-data yang dibutuhkan bersumber pada aspek kekuatan bahan tali tampar sebagai struktur kabel. Terdapat proses mendeskripsikan dan mengeksplorasi berdasarkan aspek tinjaun desain (style), konstruksi (firminitas), function (fungsi).

\subsubsection{Strategi Penelitian}

Kategori penelitian sesuai dengan konsep Buckley adalah masuk dalam kajian empiris, dengan menggunakan sarana laboratorium permodelan dan melalui proses simulasi dalam skala dan besaran yang dapat dianalisa. Penggunaan permodelan dan simulasi dapat digunakan sebagai proses interaksi yang memudahkan dalam mengkaji aspek desain, sistem konstruksi dan aspek fungsi. 


\subsubsection{Rancangan Penelitian}

- Rancangan penelitian yang digunakan dalam kegiatan ini adalah mengidentifikasi kekuatan bahan tali tampar melalui studi literatur baik dari sumber bacaan, media web, publikasi ilmiah dan penelitian yang sejenis.

- Penyusunan data baik secara teoritis dan grafis menjadi dasar untuk melakukan.

- Pembuatan model alat uji dilakukan dengan melalui metode digitalisasi dan simulasi agar data-data tersebut dapat menjadi data base yang akan digunakan sebagai bagian dari aplikasi uji kekuatan bahan tampar plastik yang nantinya diaplikasikan sebagai model rancang bangun.

- $\quad$ Analisis perilaku dan pembebanan sederhana pada model dilakukan dengan cara manual berdasarkan permodelan yang ada atau dapat juga dengan bantuan teknologi informasi tersebut.

- Analisis dilakukan untuk memperoleh berbagai aspek desain dan model yang dapat diterapkan secara aplikatif dan dapat digunakan oleh pengguna sebagai subtitusi kabel baja pada permodelan bangunan dengan skala yang lebih kecil baik secara estetika maupun struktural.

- Hasil penelitian dapat digunakan sebagai media bahan ajar kepada mahasiswa dan harapannya dapat disebarluaskan bagi kebutuhan praktis.

\section{Pembahasan}

\subsection{Kategorisasi}

Dalam kategorisasi dilakukan pemberian nama terhadap sampel atau bahan uji, pemberian nama ini berdasarkan AA/panjang tali/Ǿtali/besar keelastisan bahan/ besar pemuluran bahan/beban putus/waktu putus.

Pada percobaan ini sampel merk tali yang digunakan ada 5 merek dengan pengkodean nama sebagai berikut:

a. Beruang

Terdiri dari 3 ukuran yaitu $0.05 \mathrm{~cm}, 0.2 \mathrm{~cm}$, dan $0.7 \mathrm{~cm}$

Penamaan : AA1/10/0.05/1/9.5/1.5/4'

AA2/10/0.2 /1/7.5/1.5/5"

AA3/10/0.7/1/3/1.5/0,2"

b. Seagul

Terdiri dari 3 ukuran yaitu $0.2 \mathrm{~cm}, 0.5 \mathrm{~cm}$, dan $0.3 \mathrm{~cm}$

Penamaan : BB4/10/0.2/3/4.5/2/12"

BB5 $/ 10 / 0.3 / 1.5 / 3 / 1.5 / 5^{\prime}$

BB6/10/0.5/1/5.5/2/35"

c. $\mathrm{x}$ (tanpa merk)

Penamaan : CC7/10/0.15/2.5/9.8/1/4'

d.Indomart

Penamaan : DD8/10/0.33/1/32/1/11'7"

e. Lumba-lumba

Penamaan : EE9/10/0.05/1/30/1/23"

3.2 Pembuatan Alat Uji 


\subsubsection{Perancangan Alat: Desain Alat}

Desain alat penguji ini terdapat beberapa desain hasil rancangan, pada perancangannya memperhitungkan bagaimana gaya dan pengaruh berat timbel untuk menguji kekuatan tali tampar.Hasil perancangan adalah sebagai berikut:

Keterangan alat penguji:

A. Paku alur $25 \mathrm{~cm}$ (penggantung)

B. Lubang ukur

C. Engsel (pembuka/tutup alat)

D. alas/bidang dasar alat

E. Kayu penjepit bahan uji

F. Mistar $60 \mathrm{~cm}$

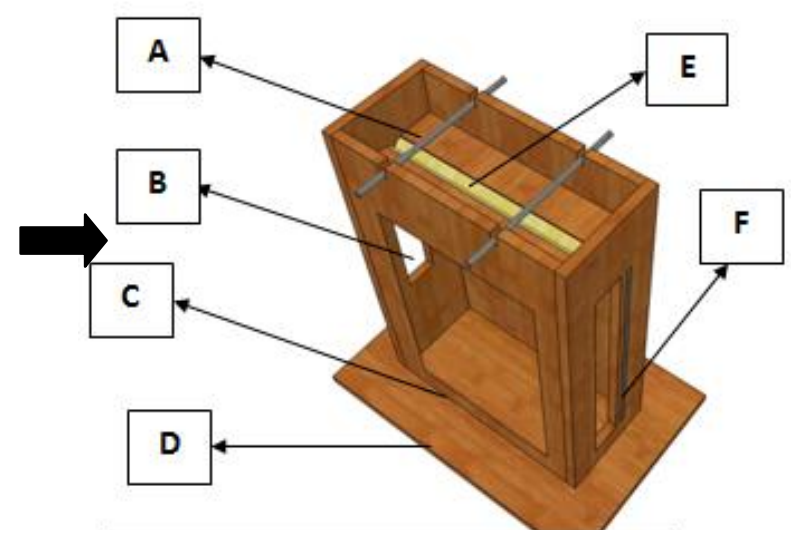

Gambar 4. Bagian-bagian Alat uji

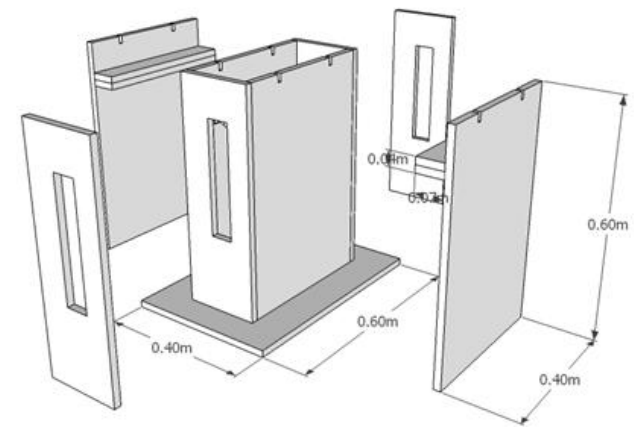

Gambar 5. Bagian-bagian Alat uji

\subsubsection{Deskripsi Alat Uji}

Alat uji ini adalah alat buatan tangan (handmade) dengan akuarasi penelitian sebatas $1 / 2 \mathrm{Kg}$ beban uji. Bahan dasar pembuatan alat uji ini adalah multiplex $1,5 \mathrm{~cm}$.

Alat dan bahan perancangan

Alat:

- paku

- penggaris

- gergaji

- lem kayu

- bor kayu 
Bahan :

- multiplek $1,5 \mathrm{~cm}$

- kayu silinder diameter $3 \mathrm{~cm}$

- mistar besi 2 buah per alat

- benang wol

- ur baut

- Paku alur $25 \mathrm{~cm}$

- Ring

- Engsel piano

\subsubsection{Deskripsi Alat Uji}

Alat uji ini adalah alat buatan tangan (handmade) dengan akuarasi penelitian sebatas $1 / 2 \mathrm{Kg}$ beban uji. Bahan dasar pembuatan alat uji ini adalah multiplex 1,5 cm.

Alat dan bahan perancangan Alat

Alat:

- paku

- $\quad$ penggaris

- $\quad$ gergaji

- $\quad$ lem kayu

- bor kayu

Bahan :

- $\quad$ multiplek $1,5 \mathrm{~cm}$

- $\quad$ kayu silinder diameter $3 \mathrm{~cm}$

- $\quad$ mistar besi 2 buah per alat

- benang wol

- ur baut

- $\quad$ Paku alur $25 \mathrm{~cm}$

- $\quad$ Ring

- $\quad$ Engsel piano

\subsection{Persiapan Penelitian}

3.3.1 Perancangan Alat: Desain Alat Bahan Penelitian

a. Tali tampar 5 merk (seagull,beruang,lumba-lumba,indomaret dan merk x)

b. Beban/timbel 10@1/2 kg dan $10 @ 1 \mathrm{~kg}$

c. Kait

d. Stopwatch

e. $\quad$ Penggaris (mistar)

f. Alat uji

g. Jangka sorong

h. Spidol marker putih 

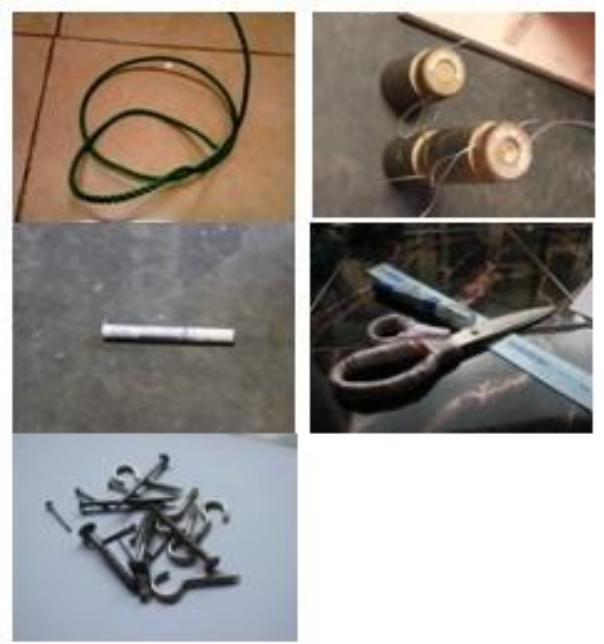

Gambar 6. Bahan Penelitian

\subsection{2. $U j i$}

a. Benda uji di masukan ke alat uji yang sudah disiapkan kemudian dijepit. Pada penelitian ini alat uji terdiri dari 4 unit alat uji
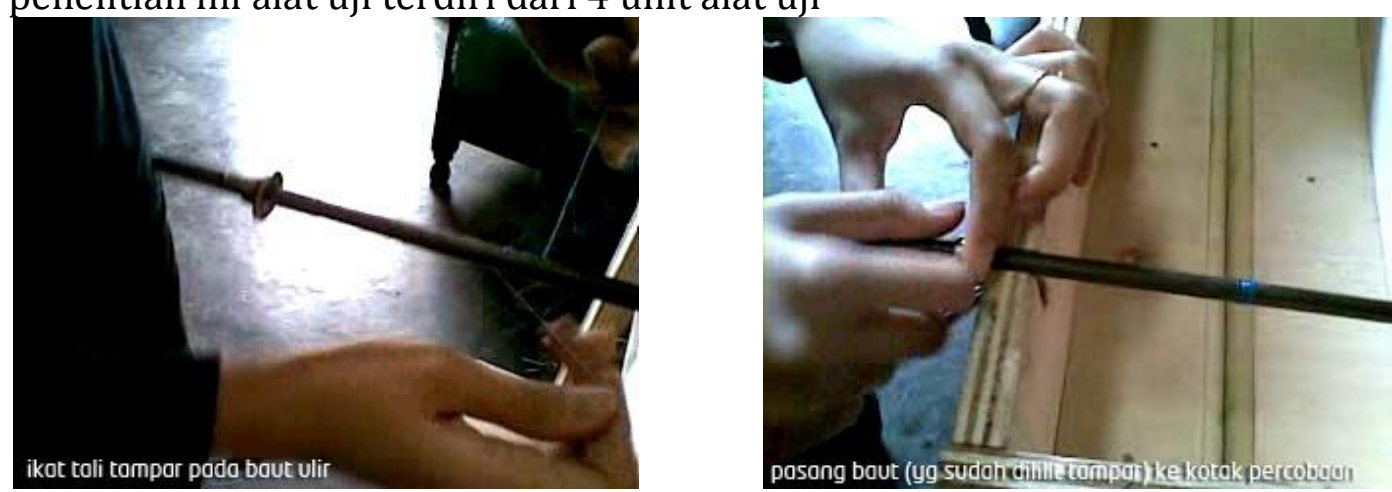

Gambar 7. Proses Pengujian

b. Beri tanda dengan spidol marker putih untuk titik nol

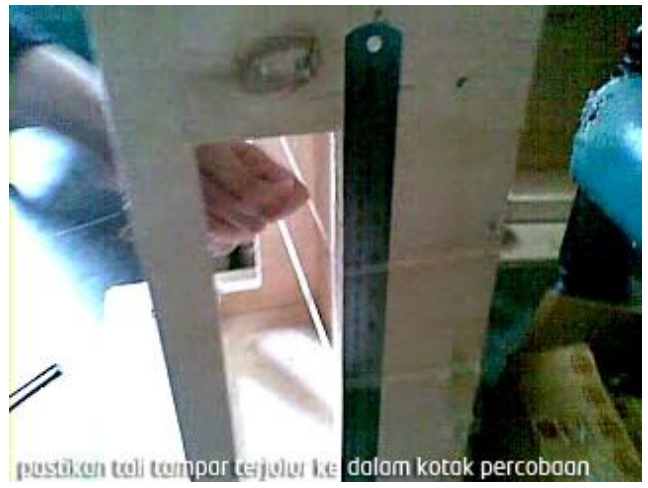

Gambar 8. Proses Pengujian 
c. Kaitkan pengait dan beban tunggu sampai 15 menit (beban pertama $1 / 2 \mathrm{~kg}$, berikutnya ditambah $1 / 2 \mathrm{~kg}$ hingga hingga sebelum pemuluran)
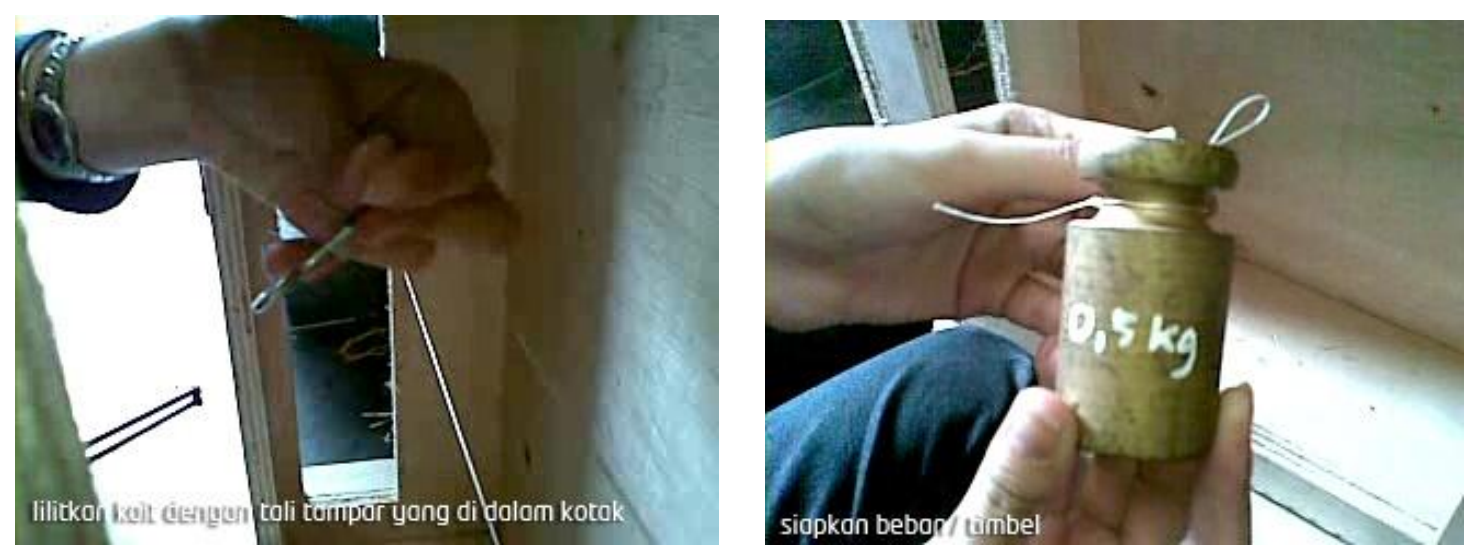

Gambar 9. Proses Pengujian

d. Catat besar keelastisan dan pemuluran benda uji .

e. Tambah beban benda uji dengan beban berikutnya $1 / 2 \mathrm{~kg}$ hingga mulur dan putus

f. Catat pada waktu dan berapa batas mulur benda uji pada tabel

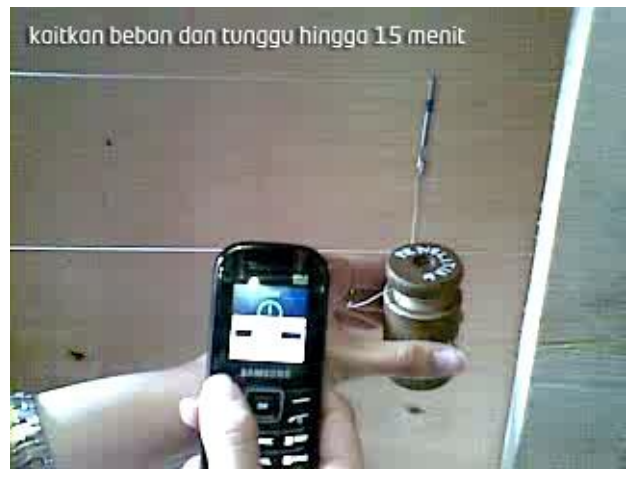

Gambar 10. Proses Pengujian

\subsection{Variabel Penelitian}

3.4.1 Variabel pengikat

a. Batas waktu tiap beban $1 / 2 \mathrm{~kg}=5$ menit

b. Merk tali tampar ada 4 jenis yaitu X, Seagul,beruang, dan lumba-lumba

\subsubsection{Variabel Bebas}

a. Jenis tali tampar.

b. Jumlah serat.

\section{Hasil Penelitian}

Dari penelitian yang telah dilakukan didapatkan hasi sebagai berikut: 
Tabel 1. Hasil Penelitian

\begin{tabular}{|r|r|l|l|l|l|l|l|l|l|l|l|}
\hline \multicolumn{2}{|c|}{ Beban } & \multirow{2}{*}{ Waktu } & \multicolumn{3}{|c|}{ Merk Seagul 0,3 } & \multicolumn{3}{c|}{ Merk Seagul 0,2 } & \multicolumn{3}{c|}{ Merk Seagul 0,5 } \\
\cline { 3 - 12 } & & $\begin{array}{c}\text { Pemulur- } \\
\text { an }\end{array}$ & $\begin{array}{c}\text { Elastisi- } \\
\text { tas }\end{array}$ & Putus & $\begin{array}{c}\text { Pemulur- } \\
\text { an }\end{array}$ & $\begin{array}{c}\text { Elastisi- } \\
\text { tas }\end{array}$ & Putus & $\begin{array}{c}\text { Pemulur- } \\
\text { an }\end{array}$ & $\begin{array}{c}\text { Elastisi- } \\
\text { tas }\end{array}$ & Putus \\
\hline 1 & 0.5 & $15^{\prime}$ & $1,5 \mathrm{~cm}$ & $0,5 \mathrm{~cm}$ & & $0,8 \mathrm{~cm}$ & 0 & & $1 \mathrm{~cm}$ & $0,5 \mathrm{~cm}$ & \\
\hline 2 & 1 & $30^{\prime}$ & $3 \mathrm{~cm}$ & $1,5 \mathrm{~cm}$ & & $2 \mathrm{~cm}$ & $1 \mathrm{~cm}$ & & $3,5 \mathrm{~cm}$ & $1 \mathrm{~cm}$ & \\
\hline 3 & 1.5 & $45^{\prime}$ & $3 \mathrm{~cm}$ & $1,5 \mathrm{~cm}$ & $5^{\prime}$ & $4,5 \mathrm{~cm}$ & $3 \mathrm{~cm}$ & & $5 \mathrm{~cm}$ & $1 \mathrm{~cm}$ & \\
\hline 4 & 2 & $60^{\prime}$ & & & & & & $12 "$ & 5,5 & & $35^{\prime \prime}$ \\
\hline
\end{tabular}

Tabel 2. Hasil Penelitian

\begin{tabular}{|l|l|l|l|l|l|l|l|l|l|l|l|}
\hline \multirow{2}{*}{ Beban } & \multirow{2}{*}{ Waktu } & \multicolumn{3}{|c|}{ Merk Beruang 0,05 } & \multicolumn{3}{c|}{ Merk Beruang 0,2 } & \multicolumn{3}{c|}{ Merk Beruang 0,7 } \\
\cline { 3 - 13 } & & $\begin{array}{c}\text { Pemulur- } \\
\text { an }\end{array}$ & $\begin{array}{c}\text { Elastisi- } \\
\text { tas }\end{array}$ & Putus & $\begin{array}{c}\text { Pemulur- } \\
\text { an }\end{array}$ & $\begin{array}{c}\text { Elastisi- } \\
\text { tas }\end{array}$ & Putus & $\begin{array}{c}\text { Pemulur- } \\
\text { an }\end{array}$ & $\begin{array}{c}\text { Elastisi- } \\
\text { tas }\end{array}$ & Putus \\
\hline 1 & 0.5 & $15^{\prime}$ & $2 \mathrm{~cm}$ & $1 \mathrm{~cm}$ & & $2 \mathrm{~cm}$ & $0,5 \mathrm{~cm}$ & & $1,5 \mathrm{~cm}$ & $0,5 \mathrm{~cm}$ & \\
\hline 2 & 1 & $30^{\prime}$ & $9,5 \mathrm{~cm}$ & $1 \mathrm{~cm}$ & & $7,5 \mathrm{~cm}$ & $1 \mathrm{~cm}$ & & $3 \mathrm{~cm}$ & $1,5 \mathrm{~cm}$ & \\
\hline 3 & 1.5 & $45^{\prime}$ & & & $4^{\prime}$ & & & $5 "$ & & & $0.2^{\prime \prime}$ \\
\hline 4 & 2 & $60^{\prime}$ & & & & & & & & & \\
\hline
\end{tabular}

\section{Tabel 3. Hasil Penelitian}

\begin{tabular}{|l|l|l|l|l|l|l|l|l|l|l|l|}
\hline \multirow{2}{*}{ Beban } & \multirow{2}{*}{ Waktu } & \multicolumn{3}{|c|}{ Merk Indomaret 0,33 } & \multicolumn{3}{c|}{ Merk x 0,15 } & \multicolumn{3}{c|}{ Merk Lumba-Lumba } \\
\cline { 3 - 13 } & & $\begin{array}{c}\text { Pemulur- } \\
\text { an }\end{array}$ & $\begin{array}{c}\text { Elastisi- } \\
\text { tas }\end{array}$ & Putus & $\begin{array}{c}\text { Pemulur- } \\
\text { an }\end{array}$ & $\begin{array}{c}\text { Elastisi- } \\
\text { tas }\end{array}$ & Putus & $\begin{array}{c}\text { Pemulur- } \\
\text { an }\end{array}$ & $\begin{array}{c}\text { Elastisi- } \\
\text { tas }\end{array}$ & Putus \\
\hline 1 & 0.5 & $15^{\prime}$ & $2 \mathrm{~cm}$ & $1 \mathrm{~cm}$ & & $4 \mathrm{~cm}$ & $2,5 \mathrm{~cm}$ & & $2,5 \mathrm{~cm}$ & $1 \mathrm{~cm}$ & \\
\hline 2 & 1 & $30^{\prime}$ & $32 \mathrm{~cm}$ & & $11^{\prime} 7^{\prime \prime}$ & $9,8 \mathrm{~cm}$ & & 4 & $30 \mathrm{~cm}$ & & $23^{\prime \prime}$ \\
\hline 3 & 1.5 & $45^{\prime}$ & & & & & & & & & \\
\hline 4 & 2 & $60^{\prime}$ & & & & & & & & & \\
\hline
\end{tabular}

Perhitungan Kekuatan Bahan Tali Tampar

Rumus perhitungan: $1 / 3 \times$ (berat saat putus $x$ banyak serat tali) $n=3$

1. merk Seagul 0,3

$1 / 3 \times(1.5 \times(55 \times 3))=82.5 \mathrm{Kg}$

2. merk Seagul 0,2

$1 / 3 \times(2 \times(25 \times 3))=50 \mathrm{Kg}$

3. merk Seagul 0,5

$1 / 3 \times(2 \times(55 \times 3+10))=117 \mathrm{Kg}$

4. merk Beruang 0,2

$1 / 3 \times(1.5 \times(25 \times 3))=37.5 \mathrm{Kg}$

5. merk Beruang 0,5

$1 / 3 \times(1.5 \times(55 \times 3))=82.5 \mathrm{Kg}$

6. merk Beruang 0,7

$1 / 3 \times(1.5 \times(100 \times 5+25))=262.5 \mathrm{Kg}$

7. merk Indomart 0,33

$1 / 3 \times(1 \times(55 \times 3))=52 \mathrm{Kg}$

8. $\quad$ merk $\times 0,15$

$1 / 3 \times(1 \times(55 \times 3))=52 \mathrm{Kg}$

9. merk lumba-lumba 0,05

$1 / 3 \times(1 \times(10 \times 3))=10 \mathrm{Kg}$ 


\section{Kesimpulan}

Sehingga menurut hasil percobaan diperoleh data yang terkuat adalah serat dari tali tampar bermerk seagul dengan kekuatan putus sampai $2 \mathrm{~kg}$ pada ukuran $0.5 \mathrm{~cm}$. Untuk pengaplikasian kepada permodelan struktur bangunan maka perlu diperhitungkan beban aman dengan mengalikan jumlah serat dengan $1 / 3$ sehingga dari hasil perhitungan diperoleh beban aman untuk tali tampar seagull adalah $117 \mathrm{~kg}$.

\section{Saran}

Percobaan ini sebaiknya dilakukan berkali-kali untuk mendapatkan data dan hasil yang tepat dan akurat perhitungannya sedangkan alat uji dapat di kembangkan lagi desainnya untuk menambah keakuratan perhitungan kekuatan tali tampar ini.

\section{Daftar Pustaka}

Schlaich, J. dan Wagner, R. (1992). “Bauen mit Seilen”, Manuskript Institut für Tragwerksentwurf-und Konstruktion - Universitat Stuttgart.

Cowan,Henry J,(1977) “The Masterbuilders” a History Of Structural And Environmental Design From Ancient Egypt To The Nineteenth Century. United States of America, JUohn Wiley and Sons.inc.

Rahmat Iskandar Fajri, Tarkono,dan Sugiyanto, 2013, Studi Sifat Mekanik Komposit Serat Sansevieria Cylindrica Dengan Variasi Fraksi Volume Bermatrik Polyester,Jurnal Fema, Volume 1, Nomor 2,

Safrudin Kiay, Andi Asgar W,dan Neny K, 2011, Penentuan Karakteristik Tali Pancing Nilon dengan Metode Uji Tarik,Prosiding Seminar Kontribusi Fisika.

Iwan Wikana dan Try Haryanto, 2007,Usaha Menambah Kuat Lentur Balok Beton Dengan Tali Rami , Majalah Ilmiah Ukrim Edisi 1/Th XII/2007. 